\title{
Liberal nationalisme og politisk teori
}

Theresa Scavenius Ph.d.-stipendiat, Institut for Statskundskab, Københavns Universitet

\begin{abstract}
Er nationalisme et fænomen, der bør bekæmpes eller er nationalisme en nødvendig forudsætning for politisk identitet og sammenhængskraft? Nyere politisk-teoretisk forskning forsøger at rehabilitere ideen om nationale fællesskaber og nationens normative betydning. Men lykkes det?
\end{abstract}

Trods grænseoverskridende konflikter som migration, klimaforandringer, terrorisme og finansiel krise er det alment accepteret, at nationalstater fortsat spiller en politisk særdeles signifikant rolle - både regionalt og internationalt. De fleste bidrag inden for international politik (IP) anerkender nationalstatens rolle i et vist omfang, og inden for politologisk forskning er nationalstaten generelt den politiske ramme, der enten implicit eller eksplicit bliver forudsat, når der tales om politiske samfund. Men selvom det er et empirisk faktum, at politik i langt de fleste tilfælde rummer et nationalt aspekt, er en fuldbyrdet nationalistisk tolkning af disse anliggender et teoretisk kontroversielt synspunkt. Den primære årsag til dette er ikke, at nationalisme som praktisk politisk position fordrer en nationalstatslig dagsorden. Når politiske partier ønsker at fremme f.eks. dansk kultur igennem nationale kulturkanoner, er der tale om legitime politiske prioriteringer. En kritisk diskussion af nationalisme kræver derimod en diskussion af synspunktets grundlæggende præmisser. Der er to alvorlige indvendinger imod nationalisme. For det første retter en kritik sig imod nationalismens eksplanatoriske kraft og den underliggende metodologiske nationalisme (Phillips 2007, 45; Eriksen \& Stjernfelt 2008). For det andet retter en kritik sig imod nationalisme som en normativ politisk teori. I nærværende artikel fokuserer jeg navnlig på denne sidstnævnte kritik, hvorimod den første indvending kun behandles indirekte $\mathrm{i}$ diskussionen af individualisme versus kommunitarisme.

Formålet med denne artikel er at introducere til den politisk-teoretiske diskussion af nationalisme. Det er artiklens hensigt at etablere, at nationalisme ikke kun bør diskuteres som empirisk problemfelt, men tillige som et normativt og analytisk begrebsniveau, der tager motivationen i det national-teoretiske argument alvorligt som alternativ til konkurrerende politisk-teoretiske argumenter for global retfærdighed og multikulturelle samfund. Artiklen ønsker at give et overblik over en af de mest fremtrædende fortalere for det moderne national-teoretiske argument, nemlig David Miller. Millers ambition er at læse nationalisme som en politisk teori, der fastholder, at nationen har en normativ betydning og derfor ikke blot skal opgives på baggrund af ønsker om global retfærdighed eller multikulturalisme (Miller 1995; 2007). Artiklen forholder sig til tre centrale debatter i litteraturen om nationalisme: (i) nationalisme vs. liberalisme; (ii) nationale vs. generelle forpligtelser samt (iii) nationalt vs. individuelt ansvar.

Inden for den moderne politiske teori er der en generel konsensus om, at nationalisme er utilstrækkelig i forhold til at begrunde, legitimere og retfærdiggøre politik (Caney 2005; Holtug 2009). Forskellen på realpolitik og politisk teori er på dette felt derfor ofte markant. Hvor det politiske felt på europæisk plan de seneste par år har været præget af en drejning imod højre, har der i den politiske teori modsat været en positiv - og af kritikere betegnet „naiv“- betoning af multikulturalisme (Dyrberg 2008; Stjernfelt \& Eriksen 2008). Men selvom multikulturalisme ud fra en realpolitisk betragtning kan hævdes at være naiv, er det ikke nødvendigvis tilfældet, hvis vi taler 
om, hvilken type af samfund vi ønsker at etablere på baggrund af eksempelvis alle individers universelle rettigheder. Med udgangspunkt i et universelt rettighedsbegreb argumenteres der inden for mainstream politisk teori typisk for liberal-egalitarisme (Rawls 1971, Dworkin 1977), multikulturalisme (Young 1990; Taylor 1992; Kymlicka 1995; Parekh 2006; Modood et al. 2006) eller kosmopolitisme (Caney 2005; Beck 2006; Pogge 2006; Singer 2009), hvor nationalstaten i bedste fald betragtes som en historisk kontingent institution eller som et nødvendigt onde. Inden for det seneste årti er det imidlertid blevet diskuteret meget, hvorvidt nationalisme bør betragtes som en selvstændig politisk teori, der identificerer ideen om, at det gode samfund er et nationalt funderet politisk samfund (f.eks. Kymlicka 2001; Buchanan 2004; Calhoun 2006; Nussbaum 2006; Miller 2007).

Efter den Kolde Krig opstod der en fornyet interesse for kulturelle og nationale fællesskaber blandt politiske teoretikere som Yael Tamir (1995), David Miller (1995), William Kymlicka (1995) og Margaret Canovan (1996). Deres fælles ærinde var at rehabilitere nationalisme som en politisk teori. Nationalisme forstås her som en position, der argumenterer for nationens normative betydning. Dvs. nationen skal ikke blot betragtes som en historisk kontingent institution, men derimod som moralsk signifikant samfundsinstitution. Nationalisme forbindes i denne sammenhæng ikke med partipolitik eller højreføjstænkning. Ambitionen er at formulere en politisk teori, der tager udgangspunkt $i$, at politiske liberale og demokratiske samfund er historisk forankrede og er nationale fællesskaber. Dette er i udgangspunktet empirisk set relativt ukontroversielt. Men argumentet for, at nationalisme er en ide om det gode samfund, er ikke kun en ide om, at nutidens politiske samfund ofte er nationale fællesskaber, men tillige en ide om, at nationale politiske samfund er gode, fordi de er liberale politiske fællesskaber. Påstanden er altså, at der udover den historiske sammenhæng mellem nationalisme og liberalisme samtidig er en konceptuel forbindelse (jf. Sørlander 2008; Støvring 2010). En antagelse er, at den nationale kultur er en betingelse for, at det er muligt at etablere og opretholde en liberal og demokratisk samfundsmodel. I den danske diskussion har senest Kasper Støvring med debatbogen Sammenhangskraft (2010) gjort sig til talsmand for et lignende argument for, at "nationen skaber et samlende værdigrundlag for det moderne demokrati“, og videre „at nationens enhed er socialt og kulturelt, snarere end politisk og statsligt betinget“ (Støvring 2010, 12).

Argumentet for en national-teoretisk politisk teori repræsenterer et interessant forsøg på at korrigere en række multikulturelle og kosmopolitiske teoretikere, der i nogen grad synes at overse den historiske relevans af nationen. Vi kan ikke komme uden om, at politik de facto tilkendegiver særlige moralske forpligtelser overfor egne borgere, som ikke på samme måde gælder for borgere $\mathrm{i}$ andre nationer. Men at fremhæve dette empiriske faktum, er ikke det samme som at hævde, at denne samfundsmodel er en normativ model for det gode samfund.

Artiklen er struktureret på følgende måde: I første del diskuterer jeg Millers argument for, at nationalisme er en liberal politisk teori. I anden del rekonstruerer jeg kritisk, hvorvidt nationale relationer (dvs. relationer imellem medlemmerne af nationen) kan tilskrives en privilegeret normativ kraft, samt hvorvidt nationalstaten (som en kollektiv størrelse) kan tilskrives en normativ betydning. Afslutningsvis konkluderer jeg, at det er tvivlsomt, hvorvidt vi alene på baggrund af de diskuterede argumenter bør tilskrive nationen en privilegeret normativ betydning.

\section{Liberalisme og nationalisme}

Liberalisme er en politisk filosofi, som traditionelt set er baseret på principper om individets lighed, frihed, politiske muligheder og retfærdig fordeling af sociale ressourcer. Det liberale ideal er et politisk samfund, der er anti-perfektionistisk, anti-paternalistisk og neutralt overfor individernes præferencer og ideer om det gode liv (Kymlicka 1989, 77). Inden for denne begrebsramme er nationalisme og kulturelle fællesskaber a-politiske entiteter, der hverken bør tilskrives en moralsk eller politisk signifikant rolle. Motiveret af forskellige påstande om, at nationale og kulturelle fællesskaber er en forudsætning for stabilitet, politisk deltagelse og legitimitet (Kymlicka 1989, 85), forsøger Miller og Kymlicka at etablere en alternativ teori, hvor liberalisme og nationalisme ikke er uforenelige størrelser (Miller 1995, 119, 130). Vi kan karakterisere dette som et forsøg på at etablere en liberal-national politisk teori, der hævder, at der er et såkaldt „symbiotic relationship" mellem liberalisme og nationalisme (Miller 2005, 113). En forudsætning for dette argument er ideen om, at individer på én gang er medlemmer af et politisk samfund som statsborgere og medlemmer af et kulturelt samfund, hvor medlemmerne deler fælles sprog, kultur og historie (Kymlicka 1989, 135).

For Miller og Kymlicka er ideen, at det er muligt at formulere en teori om nationalisme, der konstituerer en $n y$ form for nationalisme, som ikke er ekskluderende, voldelige eller xenofobisk, men derimod inkluderende, demokratisk og liberal (Kymlicka 2001, 209). Intuitionen er grundlæggende, at mange liberale og demokratiske stater er nationalstater, hvilket, som nævnt, er ukontroversielt. Alligevel kan vi ikke umiddelbart erklære os enige i, at liberalisme er forenelig med nationalisme, idet påstanden 
strider med eller udfordrer en række liberal-individuelle grundintuitioner. Spørgsmålet er, om liberal-nationalisme kan forenes med en individualisme, dvs. individets moralske værdighed og evne til at træffe selvstændige og individuelle afgørelser? Eller om der snarere er tale om en form for liberal-kommunitarisme, der i en standarddefinition identificerer individernes kapacitet til at vælge frit imellem forskellige værdier og ideer om det gode liv inden for en social og kulturel kontekst? (jf. Kymlicka 1989, 162-165).

Både for Miller og Kymlicka er det afgørende at identificere et national-teoretisk argument, som er en kommunitaristisk samfundsteori, der tager højde for fællesskabets betydning for individets menings- og viljesdannelse uden at gå på kompromis med en individualisme, dvs. individets værdighed og autonomi (Kymlicka 1989, 9; Miller 1995, 193). Som Kymlicka anfører, er det ideen, at individerne kan leve deres „life from the inside“, dvs. i overensstemmelse med deres kultur og overbevisninger om det gode liv samtidig med, at de individuelt kan forholde sig til forskellige opfattelser af det gode liv. Dvs. vurdere og revidere opfattelser af, hvad det gode liv er, vælge imellem forskellige sociale praksiser samt forstå valgene som betydningsfulde (Kymlicka 1995, 81-83). Af dette udleder Kymlicka, at vi ikke skal identificere en uovervindelig konflikt eller et fundamentalt modsætningsforhold imellem individets frihed og kollektivets kultur og politik, idet sidstnævnte konstituerer „a context of choice", dvs. en række kulturelle betingelser for individernes valg, refleksion og selvforståelse (Kymlicka 1989, 13; 1995, 76).

Miller er i udgangspunktet enig i dette. Miller hævder, at de nationale identiteter ikke er fastlagt på forhånd (Miller 1995, 195), hvilket kan betragtes som en forudsætning for, at nationale medlemmer kan forholde sig kritisk og refleksivt til, hvorfor netop deres nation er værdifuld for dem, samt vælge individuelle livsprojekter (Kymlicka 1995, 83; Kymlicka 2001, 203). Ideen er, at vi som eksempelvis danskere ikke blot følger det danske normsæt, men derimod at vi er i stand til refleksivt og kritisk at forholde os til den normative værdi af vores kulturelle fællesskab. På den anden side udelukker Miller ikke, at medlemskabet af det specifikke nationale samfund ikke står til diskussion (Miller 1995, 194) og at medlemmerne tvinges til at adaptere en national identitet gennem deres nationale sprog, sociale praksisser og historiske mærkedage, samt at dette kan ske delvist „authoritatively imposed by repression and indoctrination" (Miller 1995, 39). Når Miller ikke ser en uforenelighed imellem på den ene side tvang og liberal-nationalisme, kan det forklares ud fra, at antagelsen er, at de kollektive og natio- nale følelser kan være „hidden away in the deeper recesses of the mind" (Miller 1995, 18). De nationale identiteter kan være „unarticulated, and yet still exercise a pervasive influence on people's behaviour" (Miller 1995: 27). Dette forekommer dog at være en bemærkelsesværdig påstand. Hvordan kan de individuelle medlemmer være i stand til positivt at vurdere, hvorfor netop deres nation er værdifuld for dem (Kymlicka 1995, 81; Kymlicka 2001, 203), hvis medlemmernes nationale identitet dels er skjult, uartikuleret samt nedarvet og dermed ufravigelig (Miller 1995, 43), dels bestemmende for, hvad medlemmet oplever som værdifuldt og meningsfuldt? Hvis ambitionen er at inkorporere et individualistisk og voluntaristisk (forstået som et demokratisk, deliberativt og kritisk) element ind i den nationalistiske politiske teori, der hævder, at nationale relationer rummer en række præpolitiske, medfødte og ikke-voluntaristiske egenskaber, er det tvivlsomt, hvorvidt Millers argumentation er konsistent (Lægaard 2003, 314).

Hvis medlemmernes identitet og menings- og viljesdannelse er betinget af medlemmernes nationale tilhørsforhold, synes argumentet at implicere, at medlemmernes mulighed for refleksivitet, kritik samt valg af livsprojekter på tilsvarende vis kan betragtes som værende betinget af deres nationale tilhørsforhold. Hvis vi antager, at det er, hvad Miller argumenterer for, vil muligheden for f.eks. at vælge en social praksis være betinget af medlemmernes nationale identitet, hvorfor det liberal-individuelle aspekt vil være underlagt det kommunitaristiske aspekt, der er bredere og udtaler sig mere generelt om medlemmernes identitet og ikke kun om deres specifikke individuelle menings- og viljesdannelse. For så vidt dette er tilfældet, kan den overordnede national-teoretiske påstand mere kortfattet siges at etablere følgende: (1) Individers identitet samt menings- og viljesdannelse er konstitueret af deres nationale kultur. Formuleret således, er der tale om en stærk formulering af argumentet, og en radikal påstand, der i de fleste tilfælde vil være uforenelig med individualisme og voluntarisme. Denne stærke formulering af det national-teoretiske argument strider imidlertid med Kymlickas eller Millers overordnede ambition om at forene liberal-individuelle og liberal-nationale elementer.

Hvis vi fastholder, at den national-teoretiske ambition er at forene et individuelt aspekt med et kommunitaristisk aspekt i den liberal-nationale teori, kan vi antage, at det er muligt at tilkendegive det politiske individ en række individuelle frihedsrettigheder - på et politisk samfundsniveau, uafhængigt af, at individernes ønske og vilje - på et sociologisk og kulturelt niveau - ikke alene kan tilskrives et absolut autonomiseret individ, men derimod er influeret af den sociale kultur, det nationale sprog og 
identitet (Kymlicka 2001, 209). På den baggrund kan vi formulere en alternativ og svag formulering af det national-teoretiske argument: (1') Individers identitet samt menings- og viljesdannelse er influeret af deres nationale kultur. Den svage variant kan siges at etablere, at selvom vi accepterer, at individer på et sociologisk niveau ikke skal forstås som absolut autonome politiske væsner, men derimod som individer, der er socialiseret ind i deres nationale og kulturelle kontekst, betyder det ikke, at vi skal opgive, at de enkelte individer kan formulere livsprojekter og revidere og afvise samfundets ideer og værdier. En begrundelse er, at den sociale, kulturelle og nationale kontekst ikke udtømmende kan identificere individernes identitet og menings- og viljesdannelse. Den svage variant er relativt ukontroversiel og er ikke væsentlig anderledes end de fleste liberal-individuelle teorier, der ofte også afviser en stærk atomistisk model for individualisme. ${ }^{1}$

På flere måder foregriber dette min konklusion, at nationen kan antages at have en empirisk og kulturel relevans desuagtet den ikke bør ophøjes til en normativ doktrin - i modsætning til Millers påstand. Selvom det er uklart, hvorvidt Miller argumenterer for en stærk eller svag variant af det national-teoretiske argument, tager jeg i det følgende udgangspunkt i den svage variant - for ikke at være unfair imod Millers overordnede nationalteoretiske ambition. Jeg diskuterer, hvorvidt Miller kan retfærdiggøre, hvorfor nationale relationer bør have en signifikant betydning i forhold til, hvem vi har moralske forpligtelser overfor, samt hvorvidt nationen kan betragtes som værende en kollektiv aktør med moralsk ansvar.

\section{Nationens normative relevans}

Det er afgørende i forhold til Millers politiske teori, at der ikke udelukkende er tale om en empirisk og sociologisk definition af nationens relevans. For Millers argument er det vigtigt, at der er tale om et nationsbegreb, hvorudfra der kan udledes en særlig moralsk signifikant relation medlemmerne imellem (Miller 1995, 49). Påstanden er, at nationalitet kan tilskrives en moralsk relevans på samme måde, som individet inden for liberal-individualistiske positioner tilskrives en moralsk relevans. Moralsk relevans refererer i denne sammenhæng til tesen om, (2) at en persons moralske forpligtelser er betinget af personens nationale og kulturelle fallesskab. Hvis dette er tilfældet, kan menneskets moralske forpligtelser og ansvar begrænses til medlemmer inden for det nationale fællesskab. ${ }^{2}$ I det følgende er hensigten kritisk at diskutere Millers to argumenter for, at nationen kan tilskrives en moralsk relevans, nemlig ideen om nationale forpligtelser og nationalt ansvar.
Kernen i Millers argument er, at medlemmernes nationale identitet har en moralsk relevans, hvilket begrundes ud fra den ovennævnte national-teoretiske påstand (1'), at individers identitet samt menings- og viljesdannelse er influeret af deres nationale kultur. I On Nationality (1995) begrunder Miller "the ethics of nationality“ ud fra begrebet om „national obligations“. Argumentet er, at den kollektive nationalitet ikke blot konstituerer en moralsk arbitrær relation mellem to mennesker. I stedet er der tale om, at det er muligt at anvende de nationale relationer som et udgangspunkt for identifikation af særlige nationale forpligtelser, der ikke udledes af menneskerettigheder eller individets autonomi, men derimod ud fra medlemmernes identifikation med og følelse af national kultur og identitet (Miller 1995, 18, 23). Men hvad er begrundelsen for, at de nationale folelser og relationer kan initiere en moral-teoretisk forpligtelse? Som jeg ser det, giver Miller to begrundelser herfor. For det første argumenterer Miller for, at nationale forpligtelser har en ikke-instrumentel karakter, dvs. de tilskrives en selvstændig moralsk værdi, der ikke er et middel til at opnå noget andet. For det andet argumenterer Miller for, at de nationale forpligtelser har en instrumentel karakter. Lægaard har diskuteret Millers to instrumentelle argumenter for, at fælles nationale identiteter kan betragtes som værende et middel til at tilvejebringe betingelserne for realiseringen af liberale værdier, herunder social retfærdighed og deliberativt demokrati (Lægaard 2003, 307). Begrundelsen er instrumentel og indirekte, idet det hæudes, at nationale identiteter er forudsætningen for (social og politisk) solidaritet, som igen er forudsætningen for social retfærdighed samt demokratisk deliberation (Lægaard 2003, 307). I denne artikel fokuserer jeg på et element i det instrumentelle argument, som vi kunne kalde for Millers effektivitetsargument, der hævder, at moralske forpligtelser generelt har den „bedste effekt", hvis de forankres i en fælles national identitet.

Nationale forpligtelser, der begrundes ud fra en ikkeinstrumentel kvalitet, er moral-filosofisk mere krævende end nationale forpligtelser, der begrundes ud fra en instrumentel kvalitet. Mens førstnævnte forudsætter en særlig moralsk relation mellem nationale medlemmer, kan sidstnævnte identificeres som et utilitaristisk argument, der henviser til, at det kan være "mere praktisk“ og virke „mest nærliggende“, når alle borgere har særlige forpligtelser overfor hinanden i stedet for hele verdens befolkning. Problemet er imidlertid, at hverken den ikkeinstrumentelle eller den instrumentelle nationale forpligtelse skal vise sig at være et særligt godt argument for netop en privilegeret national forpligtelse. 


\section{Nationale forpligtelser og nærhedsprincippet}

Effektivitetsargumentet har en utilitaristisk karakter og bygger på forestillingen om, at hvis alle medlemmer hjælper de mennesker, der er tættest på, vil alle mennesker være bedst stillet (Miller 1995, 52). Ideen er, at "in order to realize the values that lie at the base of our ethical theory most effectively, it makes sense for each agent to pursue those values in relation to particular other agents rather than the whole universe of agents" (Miller 1995, 51). Kan dette effektivitetsargument begrunde vigtigheden af nationale relationer i forbindelse med moralske forpligtelser overfor andre mennesker? Vi kan forstå dette som et princip for nærhed: at det er til alles bedste, hvis alle hjælper sin nabo først. Men hvorfor skal vi føle os overbevist af denne betragtning? Der kan være situationer, hvor ideen om nationale forpligtelser modstrider dette naboog nærhedsprincip. Betragt f.eks. en situation, hvor de nationale medlemmer er tættere på ikke-medlemmer af det nationale fællesskab. Et eksempel kunne være, at man i København er geografisk tættere på svenskere i Skåne end danskere i Sønderjylland. I en katastrofesituation vil det således ud fra argumentet være mere effektivt og hensigtsmæssigt, at københavnerne hjælper svenskerne og nordtyskerne hjælper danskerne i Sønderjylland. Et andet eksempel kunne være, at en gruppe mennesker er samlet $\mathrm{i}$ en redningsbåd. Her kunne man hævde, at det mest praktiske og nærliggende er at hjælpe alle, der er i redningsbåden uafhængigt af nationale tilhørsforhold. Begge eksempler illustrerer, at nationale forpligtelser ikke alene kan identificeres gennem et nærhedsprincip.

Eksemplerne yder dog ikke helt retfærdighed overfor Millers argument. Millers begreb om tæthed angår i højere grad, hvorvidt f.eks. englændere har en legitim grund til at prioritere hjælp til englændere frem for kinesere eller afrikanere på en global skala. Miller begrunder nærhedsprincippet ud fra en antagelse om, at agenterne A og B vil være bedre i stand til at hjælpe personer fra deres egen nation frem for fremmede fra andre nationer, idet det forudsættes, at de vil forstå de nødlidendes behov og interesser bedre, dels fordi de deler kultur og social kodificering; dels fordi deres hjælp afhænger af kontingente faktorer i den sociale kontekst (Miller 1995, 74). Det forbedrer imidlertid ikke argumentet for en særlig national forpligtelse nævneværdigt, idet det synes arbitrært, hvorfor Millers subsidiaritetsprincip kun omfatter det nationale fællesskab, og ikke f.eks. regionale eller kommunale fællesskaber - eller endog andre typer af fællesskaber, såsom faglige, sociale eller familiære.

„Nærhed“ forekommer ikke at være et tilstrækkeligt kriterium for at begrunde de nationale relationers moralske relevans. Miller anerkender, at det nationsbegreb, som ligger til grund for hans argumentation, ikke kan tage udgangspunkt i en ansigt-til-ansigt relation mellem mennesker, idet nationerne ofte er for store (Miller 1995, 32). Alligevel antager Miller, at der findes en analog relation mellem familiemedlemmer og nationale medlemmer, hvor forskellen mellem dem refererer til forskellige grader af tæthed og dermed til omfanget af forpligtelser (Miller $2007,104)$. I denne variant af argumentet tilskrives princippet for nationale forpligtelser en lignede karakter som relationen mellem familiemedlemmer og naboer. Hvis vi forestiller os, at et barn er blevet væk, vil forpligtelsen til at finde barnet ifølge dette argument variere fra familien og naboerne, der har en stor forpligtelse, til landsbyen og nationen, der har en relativt set mindre forpligtelse (Miller 1995; 2007: 104; Holtug 2009: 12-13).

Det skal dog bemærkes, at det ikke nødvendigvis er hensigtsmæssigt - betragtet ud fra en traditionel opfattelse af universelle forpligtelser - at definere moralske forpligtelser ud fra begrebet om nationale følelser. En påstand kunne være, at de mennesker, der leder efter barnet, handler ud fra et ønske om at fremme det gode i sig selv. Hvis agent A f.eks. er turist $i$ en landsby, hvor et barn er kommet til skade, vil agent A have en forpligtelse til at bistå en eventuel behandling af barnet - uafhængigt af A's i øvrige (ringe) kendskab og relation til barnet og landsbyen. Dette er dog ikke uforeneligt med Millers tese forstået som, at faktorer som familie, landsby og nationalitet eventuelt kan modificere det generelle moralske anliggende (Miller 2007, 13). Men selvom vi accepterer, at nationalitet kan fungere som modifikation af den generelle moralske forpligtelse, men dog ikke så stærkt som modifikationen fra familie og venner, er der ikke tale om et stærkt argument for en særlig national forpligtelse, men måske snarere for lokale forpligtelser, som borgere i små landsbyer bør tilskrive hinanden. Omvendt kan det ikke afvises, at (politiske) samfund fungerer - i overensstemmelse med effektivitetsargumentet - bedst og mest stabilt, hvis de bygger på en fælles følelse af solidaritet og forpligtelse over hinanden. Men, som også Lægaard viser, er det uklart, hvorvidt Millers forpligtelses- og solidaritetsbegreb er afhængigt af hans ide om nationale identiteter og fællesskaber. Og hvis det er, kan det hævdes at stride imod Millers overordnede ambition om at identificere en liberal-nationalisme, der er forenelig med individualisme, demokratisk deliberation og kritik (Lægaard 2003, 316).

\section{Værdifulde nationale forpligtelser}

Hvis vi vender tilbage til spørgsmålet om den ikke-instrumentelle nationale forpligtelse, kan vi konstatere, at dette argument heller ikke fungerer som en tilstrækkelig be- 
grundelse for, at de nationale identiteter har en særlig moralsk signifikans. Et problem er, at den nationale forpligtelse forudsætter, at de nationale identiteter per definition konstituerer en værdifuld karakter, og derved forudsætter Miller det, han egentlig gerne vil bevise - nemlig at nationalitet er værdifuld for medlemmerne (Miller 1995, 65). Miller antager, at hvis agent A hjælper en studerende fra sit eget universitet frem for andre studerende fra andre universiteter, sker dette ikke af instrumentelle årsager, men ud fra ,the motivational strengths of ethical ties" (Miller 1995, 66). For at understrege vigtigheden af dette forhold, fremhæver Miller, at det samme gør sig gældende, hvis to mennesker har behov for at komme på hospitalet, men agent A kun kan hjælpe én af dem. Ifølge Miller vil agent A prioritere den, der tilhører A’s nære livsverden, dog under forudsætning af, at den anden ikke har et større behov (Miller 1995, 66). Det skelsættende ved det national-teoretiske argument er, at det antages, at det nationale fællesskab kan generere en række supplerende rettigheder, der rækker udover de universelle rettigheder. Det nationale fællesskab konstituerer ifølge Miller en række rettigheder, der er mere omfattende end dem, der kan tilskrives ikke-medlemmer generelt. Af dette slutter Miller, at agent A skal prioritere mellem nationale medlemmer og ikke-medlemmer på samme måde, som A prioriterer imellem studerende fra sit eget universitet frem for studerende fra andre universiteter. Omvendt betyder det ikke, at de etiske fordringer, der følger med nationsbegrebet, kan retfærdiggøre et brud på de universelle menneskerettigheder. Det er ikke tilladt at slå andre mennesker ihjel eller skade andre mennesker - vel at mærke, hvis nationen ikke er i krig, som Miller tilføjer (Miller 1995, 78).

Hvis vi vender tilbage til det ovennævnte hospitalseksempel, er det nationale tilhørsforhold imidlertid hverken en tilstrækkelig eller nødvendig betingelse for hjælp, idet „behovet" for behandling har en højere relevans end personens nationalitet. Her er agentens forpligtelse overfor det nationale medlem mindre end den universelle forpligtelse, som alle mennesker har overfor nødlidende mennesker. Ifølge Miller bør vi med andre ord acceptere en række nationale forpligtelser, der ikke er ubetingede, idet hensynet til „behov" altid vejere tungere end nationalitet. Argumentet for nationens moralske relevans er derfor på flere måder mangelfuldt, såfremt præmissen bygger på ideen om ikke-instrumentelle nationale forpligtelser.

\section{Kollektiv og national ansvarlighed}

Mens Miller i bogen On Nationality (1995) betoner de speciale nationale forpligtelser, som de enkelte borgere føler og tilskriver hinanden, spiller begrebet national an- svarlighed en central rolle i hans seneste bog National Responsibility and Global Justice (2007). En af Millers overordnede teser er, fordi (3) nationer er kollektive agenter, (4) bor alle nationer betragtes som agenter, der er (outcome) ansvarlige overfor egne handlinger samt konsekvenserne af disse. (3) er en empirisk antagelse om, at der findes en tilstrækkelig grad af konvergens i attitude og overbevisning inden for nationens majoritet (Miller 2007, 126), hvilket begrundes ud fra den ovenfor nævnte tese (1') om, at individers identitet samt menings- og viljesdannelse er influeret af deres nationale kultur. En nation konstituerer altså en gruppe med et diakront identitetsfællesskab (dog uden at ekskludere tilhørsforhold til andre fællesskaber) (Miller 2007, 124), der antages at være numerisk set identisk over tid (Lippert-Rasmussen 2009, 116-117).

På baggrund af dette nationsbegreb udleder Miller et begreb om national ansvarlighed, dvs. et argument for, at alle nationer bør betragtes som agenter, der er ansvarlige for egne fortidige, nutidige og fremtidige handlinger samt konsekvenserne af disse (Miller 2007, 111). ${ }^{3}$ På samme måde som et individ kan være ansvarlig for sine handlinger, er antagelsen, at nationer kan være ansvarlige for deres handlinger. Det spørgsmål, som jeg i det følgende vil beskæftige mig med, er, hvorvidt nationen som en kollektiv aktør kan tilskrives ansvarlighed og dermed opfattes som en moralsk relevant størrelse.

Før jeg kommer til diskussionen om national ansvarlighed, vil jeg kort skitsere ideen om kollektiv ansvarlighed i forhold til individuel ansvarlighed. Vi kan spørge, hvorfor er kollektivt ansvar overhovedet relevant? Er det ikke mere naturligt at antage, at den person, der forårsager et givet resultat skal tage ansvaret for handlingen? I forhold til at definere individuel ansvarlighed, er der flere muligheder. En mulighed, som Virginia Held og Philip Pettit fremhæver, er, at agent A kan stilles til ansvar for en handling $\mathrm{Q}$, hvis A har viden om, at handlingens konsekvenser kan have et moralsk forkasteligt resultat $\left(\mathrm{Q}_{\mathrm{k}}\right)$, men foretog handlingen alligevel (Held 1970, 472; Pettit 2007, 174). Et eksempel er agent A, der kører på en smal landevej med en for høj hastighed. I denne situation bør agent $\mathrm{A}$ vide, at denne handling kan have den konsekvens $\mathrm{Q}_{\mathrm{k}}$ : , at køre et menneske ihjel“. På grund af, at vi kan antage, at agent $\mathrm{A}$ burde kende handlingens (moralske) konsekvenser, kan vi stille agent A til ansvar for handling Q på grundlag af handlingens (moralske) konsekvenser. ${ }^{4}$ I forhold til ideen om kollektiv ansvarlighed er det imidlertid afgørende, hvorfra agent A har viden om handlingers eventuelle (moralske) konsekvenser. Som nævnt ovenfor er forudsætningen for ideen om nationen som en kollektiv ansvarlig aktør, at de enkelte personers identitet og menings- og viljesdannelse er influeret af det 
nationale fællesskab. Vi kan derfor forstå Miller således, at den nationale kultur rummer en normativ standard for, hvordan det kan forventes, at en normal person vil eller bør handle i en konkret situation (Miller 2007, 93-96).

Men selvom vi accepterer, at vores nationale kultur har lært os de normer, som vi vurderer handlinger og handlingers konsekvenser ud fra, er det vigtigt at holde sig for øje, at det ikke i alle tilfælde er muligt at forudse handlingers (moralske) konsekvenser. Et eksempel på dette er, hvis den kausale sammenhæng er indirekte og kompleks. Det kan f.eks. hævdes, at det er svært at se det moralsk forkastelige i handlingen „at købe en liter mælk fra firma X“ i det lokale supermarked, såfremt det ikke inddrages, at den danske agent A derved har en fordel af, at „firma X kan sælge billig mælk i Danmark, fordi firma X får støtte til at sælge pulvermælk i Afrika, hvilket destabiliserer og udkonkurrerer den afrikanske mælkeproduktion“. Ved at købe mælken kan den danske agent A siges at være (med)ansvarlig for den økonomiske situation i Afrika, fordi denne kan hævdes at være en aggregeret konsekvens af agenters handlinger.

Spørgsmålet er nu, hvem der er ansvarlig for den aggregerede konsekvens. Er det alle de enkelte individer, der hver især er ansvarlig for deres del af handlingens konsekvens? Eller kan vi tale om form for kollektiv ansvarlighed på et aggregeret niveau? Hvis vi tager udgangspunkt i begrebet om kollektiv ansvarlighed er pointen, at flere personer kan tilskrives ansvar end de handlende enkeltindivider. Andre personer, som indirekte har bidraget til handlingen eller som har haft en fordel af den pågældende handling, kan ligeledes stilles til ansvar (Miller 2007, 103-104). Dette gælder f.eks. den danske agent A i mælke-eksemplet, der har fordel af, at firma X får støtte til at sælge pulvermælk i Afrika, fordi firma X samtidig sælger billig mælk i Danmark. Et andet eksempel er, at de mennesker, der har holdninger, som understøtter et opinionsklima, hvor en pågældende handling finder sted, også kan tilskrives et ansvar (Miller 2007, 118). Ifølge Miller gælder dette endda også for dem, der er kritiske overfor denne offentlige opinion (Miller 2007, 118; 121). Selvom dette på paradoksal vis kan være rigtigt, mener jeg alligevel, at der er tale om et problematisk argument. Hvis vi kigger på et mere ekstremt eksempel, kan vi spørge, hvorvidt jøderne var medskyldige i Holocaust mod jøderne? Miller afviser, at jøderne skulle være medskyldige i Holocaust, og at kurderne var medskyldige i angrebene initieret af Saddam Hussein (Miller 2007, 132), men begrundelsen er uklar, idet det i princippet ligger implicit i Millers begreb om kollektiv ansvarlighed, at alle - også kritikere og modstandere - medvirker til, at det givne hændelsesforløb kunne ske.

\section{Kollektiv og individuel ansvarlighed}

Men kan vi overhovedet tale om ansvarlighed, hvis der ikke kan identificeres en individuel aktør, der kan sættes i direkte relation til en given handling? En grundintuition er, at kollektiv ansvarlighed bryder med den liberal-individualistiske samfundsmodel, hvor det kun er enkeltindivider, der kan tilskrives ansvar for deres singulære handlinger. Ansvar hænger sammen med muligheden for straf og skyldspådragelse. Man kan sige, at domstolssystem og retspolitik i liberale demokratiske stater bygger på, at enkeltindivider kan tilkendes ansvar og straf for deres handlinger (Pierik 2008, 465). Accepterer vi derimod begrebet om kollektiv ansvarlighed, er der ikke den samme direkte sammenhæng mellem ansvar, skyld og straf. Hvis f.eks. agent $\mathrm{A}$ krænker agent $\mathrm{B}$ med nedværdigende udtalelser, ville man kunne hævde, at det ikke alene er agent $A$, der er skyldig og ansvarlig for disse udtalelser. En række omstændigheder og en række personer kan være medskyldige, fordi de igennem deres måske racistiske udtalelser kunne have medvirket til, at det føltes legitimt eller oplagt for agent $\mathrm{A}$ at ringeagte agent $\mathrm{B}$ på en moralsk forkastelig måde. Derved er der flere personer, der bør tilskrives ansvar for, at agent $\mathrm{A}$ var nedværdigende overfor agent $\mathrm{B}$. Det problematiske ved denne forståelse af kollektiv ansvarlighed er dog som nævnt, at det risikerer at fjerne det personlige ansvar fra den enkelte handling (Pierik 2008, 478) samt muligheden for individuelt fravalg. Hannah Arendt hævder, at et egentligt fravalg kun kan realiseres ved emigration. En konsekvent udlægning kunne dog være, at emigration i sig selv kan have en indirekte effekt på de handlinger, som nationen udfører, hvorfor de, der emigrerer, ligeledes kan stilles til ansvar for det nationale kollektivs handlinger. For at undgå denne udlægning, der risikerer at ende i en endeløs regres, kan vi støtte os til V. Held, der forsøger at løse problemet, hvordan det individuelle ansvar kan bibeholdes, ved at hævde, at en gruppe kun kan tilskrives kollektiv ansvarlighed, „hvis de kunne have haft ageret som en kollektiv agent [...], men afviste at gøre det“ (Held 1970; Pierik 2008, 479). Det er kun dem, som kan handle anderledes, der kan stilles til ansvar for den pågældende handling. Det er et vigtigt korrektiv i forståelsen af kollektiv ansvarlighed. For at f.eks. agent A kan stilles til ansvar kræver det altså, at A dels kunne have haft handlet anderledes og valgt handling $Q$ frem for handling Y, dels havde kendskab til forskellen mellem konsekvenserne af handling $\mathrm{Q}_{\mathrm{k}}$ og $\mathrm{Y}_{\mathrm{k}}$.

En modifikation af ideen om kollektivt ansvar kan derfor etablere, at alle individer ikke bærer den samme andel ansvar og skyld (Pierik 2008, 473). Hvis vi f.eks. kigger på et historisk og ekstremt eksempel, kan det hævdes, at selvom det er relevant at lægge ansvaret og skyl- 
den for Holocaust på flere end blot enkeltpersoner (f.eks. Hitler eller Eichmann), hvilket blandt andet Arendt har forsvaret, betyder dette ikke, at vi ikke kan identificere en fundamental forskel på Eichmann og en menig tysker i 1943. Hvis vi accepterer denne modifikation, kan vi anvende et begreb om kollektiv ansvarlighed samtidig med, at det er muligt at begrunde en særlig straf til individuelle personer for deres handlinger, hvis vi altså antager, at f.eks. Eichmann kunne have handlet anderledes i modsætning til den menige tysker i 1943 samt havde viden om de moralske konsekvenser af $Q_{k}$ (f.eks. koncentrationslejr) og $Y_{k}$ (f.eks. ikke-koncentrationslejr). Dette synes at give god mening, men det er ikke sikkert, at det er, hvad Miller argumenterer for. Hvis argumentet er, at individers identitet samt menings- og viljesdannelse er betinget eller influeret af den nationale kultur, som omtalt ovenfor, er det ikke uden videre muligt at isolere Eichmanns handlinger fra fællesskabet og den nationale kultur. Det afgørende spørgsmål for Miller og Arendt er snarere, hvilket ansvar vi kan pålægge de menige tyskere, der har været med til at forme det politiske klima og den (nazistiske) kultur, der muliggjorde, at Eichmann kunne transportere jøder og andre til koncentrationslejre og udryddelseslejre som en rationel virksomhed. Selvom Eichmann kan tilskrives et større moralsk ansvar end den menige tyske, svarer det netop ikke på hvilken af type af ansvar, vi kan tilskrive dem, der har bidraget til et bestemt politisk klima eller har opretholdt en bestemt kulturel praksis, som på indirekte vis kan hævdes at have muliggjort Eichmanns handlinger.

\section{National ansvarlighed}

Selvom Miller lægger modellen for kollektiv ansvarlighed, hvor flere personer kan tilskrives ansvar til grund for begrebet om national ansvarlighed, forekommer det mig, at Miller med ideen om national ansvarlighed går et skridt videre ved at inkludere det kollektive fallesskab, kulturen og nationen som en medansvarlig agent. ${ }^{5}$ Ambitionen er at indfange både de humane og ikke-humane forhold - som i bredere forstand er kausalt medansvarlighed for et givent handlingsforløb (Miller 2009, 87). Miller bidrager derved med et interessant forsøg på at modificere ideen om det individuelle ansvar ved at inddrage de indirekte og kulturelle aspekter af ansvarlighed, der ikke kan pågribes i handlingsøjeblikket.

Som jeg forstår Miller, er en af hans ideer, at det er muligt at tilkendegive den kollektive nation eller kultur en del af medansvaret for de situationer, hvor det ikke er muligt at tilskrive enkeltpersoner ansvaret (Miller 2009, 129). Miller giver et eksempel på dette: "If after democratic debate $[. .$.$] a policy is rejected, then we can legiti-$ mately say that the nation in question is collectively responsible for the consequences of population growth: its culture is such that is prefers large families to, let us say, less crowded roads and cities" (Miller 2007, 128). Miller sondrer imellem demokratiske og ikke-demokratiske samfund, men i begge tilfælde kan vi forklare handlinger eller mangel på handlinger ud fra „beliefs and values that are common national property" (Miller 2007, 128). Hvis nation A har store familier frem for en god infrastruktur, kan ansvaret blandt andet tilskrives nationens kulturelle præferencer og værdier.

Hvis vi ikke kun er interesseret $i$ at tilskrive den kausale sammenhæng mellem agent $\mathrm{A}$, handling $\mathrm{Q}$ og konsekvens $Q_{k}$, kan vi ifølge Millers terminologi tale om „outcome-responsibility“. Outcome-ansvarlighed identificerer de tilfælde, hvor en agent kan krediteres eller debiteres for et forhold, men hvor fordele og ulemper ikke bør ændres eller kompenseres, så længe begge dele tilfalder agent A (Miller 2007, 87, 90). Tager vi eksemplet med nation $\mathrm{A}$, der har store familier, men dårlig infrastruktur, kan vi altså kreditere eller debitere nation $\mathrm{A}$ for denne situation, men vi kan ikke umiddelbart vurdere, hvorvidt der er tale om et moralsk godt eller dårligt samfund og dermed tilskrive nationen „moral responsibility“ (Miller 2007, 89). I forhold til spørgsmålet om, hvorvidt andre nationer $\mathrm{B}$ og $\mathrm{C}$ bør hjælpe nation $\mathrm{A}$, fordi nation $\mathrm{A}$ har en dårlig infrastruktur og derfor givetvis også en dårlig $ø$ konomi sammenlignet med nation B's og C's økonomi, kan nation A ikke alene på grund af denne ulighed gøre krav på økonomisk støtte eller anden form for hjælp, idet nation $\mathrm{A}$ må tage ansvaret for konsekvenserne af deres prioriteringer (Miller 2007, 100-101). ${ }^{6}$ På denne baggrund foreslår Miller, at nationen er en politisk og moralsk relevant aktør, fordi nationen på et kollektivt og kulturelt niveau rummer en række værdier, politikker og normer, der er medbestemmende for individernes og nationens handlinger og ikke-handlinger. Selvom Miller fremhæver, at f.eks. vestlige nationer er forpligtet til at hjælpe andre nationer i forbindelse med hungersnød, naturkatastrofer eller lignende, er Millers grundide, at vi ikke bør betragte alle (fattige) nationer ,simply as victims“, (Miller 2007: 236), men derimod som ligeværdige (kollektive) aktører, der træffer selvstændige valg og derfor kan pådrages ansvar for deres handlinger. Derfor skal nationer både holdes ansvarlige for "the benefits and burdens they create for their own members" og "for the impact that their actions have on outsiders" (Miller 2007, 134).

Et ubesvaret spørgsmål forbliver dog, hvordan man stiller en nation eller en kultur til ansvar? Vil det ikke altid være medlemmerne af nationen, der de facto vil blive 
holdt ansvarlige for nation A's økonomi - og ikke nation A som sådan. Det vil i så fald betyde, at de enkelte medlemmer af nationen tilskrives ansvar selvom den enkelte person (i) ikke har viden om de langsigtede konsekvenser af denne førte politik eller de kulturelle normer, (ii) ikke nødvendigvis har kontrol over situationen eller (iii) ligefremt aktivt har forsøgt at modarbejde den givne situation (Lippert-Rasmussen 2009, 111). Som Miller formulerer det: "we find that the pattern of family relations in a particular country, and the number children who are on average produced, corresponds to the religious or other cultural values of the nation in question. Here there is no deliberate decision to behave in a particular way or to adopt a particular practice, but nevertheless what happens reflects the national culture in a fairly direct sense" (Miller 2007, 126). Når vi taler om kulturel og national ansvarlighed, risikerer vi at implicere en form for uomgængelighed, der umuliggør et individuelt fravalg fra deltagelse i den kollektive kultur eller nations handlinger (Arendt 2003, 150). Men måske er det netop Millers pointe, at individet ikke kan stilles til ansvar for forhandling Q, hvis det er nationens og kulturens (mangelfulde) moralbegreber, der konstituerer individets viden om moralske konsekvenser $\left(\mathrm{Q}_{\mathrm{k}}\right)$. Herved er vi tilbage ved den national-teoretiske påstand (1'), at den nationale kultur influerer medlemmernes identitet og begrebsverden. Accepteres (1'), kompliceres forholdet mellem individuelt, kollektivt og nationalt ansvar markant.

Til trods for udfordringerne i forhold til at forene de individuelle, kollektive og kulturelle ansvarsområder, bør vi betragte Millers ambition som et interessant forsøg på at udvide rammen for hvem og hvad, der kan være ansvarlige for et givent handlingsforløb eller en given politik. Det ændrer dog ikke på, at det stadig er uklart, hvorfor det netop er det nationale fællesskab, der på et empirisk niveau tilskrives en særlig stor betydning til forskel fra f.eks. religiøse, ideologiske eller familiære fællesskaber (Pierik 2008, 489-491; Lippert-Rasmussen 2009, 117). På den baggrund kan det kortfattet i forhold til aktuelle politiske diskussioner konkluderes, at selvom det er muligt at identificere en historisk og empirisk sammenhæng mellem f.eks. dansk nationalitet og det eksisterende politiske samfund, implicerer det ikke, at vi alene af den grund bør tilskrive dansk nationalitet en særlig normativ signifikans.

\section{Konklusion}

Accepterer vi en liberal-individualistisk teori som standardmodel for moderne politisk teori, indebærer det national-teoretiske argument, som det formuleres af Kymlicka og Miller, en række relevante udfordringer, der kalder på en konstruktiv dialog. I denne artikel har jeg for det første diskuteret, hvorvidt det national-teoretiske argument muliggør en ny og innovativ model for, hvordan et individualistisk aspekt kan forenes med et kommunitaristisk aspekt inden for det nationale fællesskab. Som jeg har vist, er der to tolkninger til rådighed; enten kan vi forstå det national-teoretiske argument som en sterk påstand, der i udgangspunktet er uforenelig med liberal-individualisme, eller som en svag påstand, der er forenelig med liberal-individualisme, men omvendt ikke repræsenterer en ny model for individets rolle i nationale og kulturelle fællesskaber, idet de fleste liberal-individualister vil hævde noget tilsvarende.

Dernæst har jeg med udgangspunkt i den svage påstand diskuteret, hvorvidt Millers argumentation for nationens normative signifikans i forhold til identifikationen af moralske forpligtelser og ansvar udgør en trussel over for en gængs liberal-individualistisk forståelse af forpligtelser og ansvar. Hvor Miller argumenterer for særlige nationale forpligtelser, mangler han en begrundelse for, hvorfor netop de nationale frem for andre typer af fællesskaber bør tilskrives en særlig moralsk rolle. På den anden side må vi medgive, at Miller inddrager en række væsentlige forhold med henblik på at diskutere, hvorvidt kulturelle, sociale og nationale fællesskaber som kollektive aktører kan tilskrives et moralsk ansvar, der rækker udover den gængse opfattelse af individuel og kollektiv ansvarlighed.

Afhængigt af hvordan man stiller sig til den nationalteoretiske påstand om de nationale kulturers betydning for individers identitet, herunder individets menings- og viljedannelse, kan det overordnet konkluderes, at ideen om national ansvarlighed bør spille en ikke ubetydelig rolle i moderne politisk teori og skal inddrages som analysefelt. Som jeg har argumenteret, er balancen mellem en overbetoning og en underbetoning af „det nationale“ i politisk teori permanent til stede. På et første ordens niveau er det for det empiriske blik evident, at nationalstaten og nationale fællesskaber spiller en fortsat afgørende rolle for politik inden for stort set alle samfundsområder - og at vi alene af denne grund ikke teoretisk kan annullere det nationales betydning. Men uagtet at nationale fællesskaber og kulturer skal tilskrives en udbredt empirisk relevans, er vi ikke af denne grund forpligtet på at acceptere en omfattende kritik af den liberal-individualistiske standardmodel, eller på at acceptere en stærk nationalteoretisk antagelse som en gyldig normativ maksime, der præsenterer en alternativ model for korrespondancen mellem liberalisme og individualisme. Som så ofte er den teoretiske udfordring at ramme en balance mellem det nationales fortsatte empiriske og normative betydning og samtidig fastholde et universalistisk perspektiv på individets rettigheder og transnationale politiske garantier. 


\section{Noter}

1. Både Mill, Rawls og Dworkin kan læses således, at individuel frihed og individuelle valg i et eller andet omfang er afhængig af kulturelle strukturer og samfund (Kymlicka 1989, 75).

2. Dette skal ikke forstås således, at Miller argumenterer for, at det kun er nationale relationer, der kan begrunde moralske forpligtelser. Miller betoner, at vi udover vores forpligtelser overfor nationale medlemmer også har forpligtelser overfor f.eks. nødlidende mennesker i andre nationer. Ideen om nationale forpligtelser suppleres derfor med et argument for en række generelle forpligtelser, der er særligt relevante i forhold til hungersnød, flygtninge og klimaforandringer. De generelle forpligtelser udleder han på baggrund af et humanitært princip for universelle menneskerettigheder - i modsætning til de nationale forpligtelser, der er bundet til et retfærdighedsprincip (Miller 2007, kapitel 7). Påstanden er, at de specifikke nationale forpligtelser og de universelle forpligtelser kan komplementere hinanden. I denne artikel forholder jeg mig udelukkende til Millers tese om de specielle nationale forpligtelser.

3. Lippert-Rasmussen viser, at Millers argument for national ansvarlighed på baggrund af to modeller „the like-minded group“ og ,the cooperative practice" ikke er overbevisende (Lippert-Rasmussen 2009, 124). Det er uklart, hvorfor nationale og diakrone fællesskaber spiller en større rolle end f.eks. synkrone og ideologiske fællesskaber på tværs af nationer.

4. Det er endda muligt at stille alle, der kører for stærkt, til ansvar for denne handling som en kollektiv gruppe. Argumentet er, at det er tilfældigt hvem, der i sidste instans kører en person ihjel. Men alle dem, der kører for stærkt, har sat sig selv i den situation, hvor det er muligt, at de kan køre en person ihjel. Hvem, der faktisk kører en person ihjel, er således en tilfældighed. En tilfældighed, der kan hævdes at være moralsk arbitrær (Feinberg 1968, 674-688).

5. En anden model finder vi i Arendts sondring mellem ansvar og skyld. Her er det muligt at adskille den politiske kollektive ansvarlighed fra den personlige moralske skyldfølelse (Arendt 2003, 46). Hvis man føler sig skyldig, er man solidarisk med et givet kollektivt fællesskab eller nation. I forhold til Eichmann-eksemplet kan alle tyskere kollektivt set føle en moralsk skyldfølelse, men de kan ikke stilles til ansvar eller straffes for deres handlinger (Pettit 2007, 176).

6. Et afgørende aspekt ved Millers forståelse af kollektiv og national ansvarlighed er begrebet „remedial responsibility“, der identificerer de forpligtelser, nationer har overfor andre (nødlidende) nationer (Miller 2007). I denne artikel inddrager jeg ikke dette aspekt af Millers teori.

\section{Referencer}

Arendt, H 2003, „Collective Responsibility“, in H Arendt, Responsibility and Judgment, New York, Schocken Books.

Beck, U 2006, Cosmopolitan Vision, Oxford, Polity Press.

Buchanan, A 2004, Justice, Legitimacy, and Self-Determination. Moral Foundation of International Law, Oxford, Oxford University Press.

Calhoun, C 2006, Nations Matter: Culture, History, and the Cosmopolitan Dream, New York, Routledge.

Canovan, M 1996, Nationhood and Political Theory, Cheltenham, Edward Elgar Publishing limited.
Caney, S 2005, Justice Beyond Border - A Global Political Theory, Oxford, Oxford University Press.

Dworkin, R 1977, Taking Rights Seriously, London, Duckworth.

Dyrberg, T C 2008, „Identitetspolitisk offerideologi og hykleri - om venstreorientering i dag“, Kritik, no. 188, pp. 3-18.

Feinberg, J 1968, „Collective Responsibility“, The Journal of Philosophy, vol. 65, no. 21, Sixty-Fifth Annual Meeting of the American Philosophical Association Eastern Division, vol. 7, pp. 674-688).

Eriksen, \& F Stjernfelt, 2008 Adskillelsens politik. Multikulturalismeideologi og virkelighed, København, Lindhardt \& Ringhof.

Held, V 1970, „Can a Random Collection of Individuals be Morally Responsible?” The Journal of Philosophy, vol. 67, no. 14, pp. 471-481.

Holtug, N 2009, „The Cosmopolitan Strikes Back. A Critical Discussion of Miller on Nationality and Global Equality“, Paper.

Kymlicka, W 1989, Liberalism, Community and Culture, Oxford, Clarendon Press.

Kymlicka, W 1995, Multicultural Citizenship, Oxford, Oxford University Press.

Kymlicka, W 2001, Politics in the Vernacular - Nationalism, Multiculturalism, and Citizenship, Oxford, Oxford University Press.

Lippert-Rasmussen, K, 2009 „Responsible nations: Miller on national responsibility“, Ethics \& Global Politics, vol. 2, no. 2, pp. 109-130.

Lægaard, S 2003, „Liberal nationalisme og begrebet om nationen“, Politica, vol. 35, no. 3 (oktober), pp. 303-318.

Lægaard, S 2009, „Multi-kulti: Kulturalismens veje og vildveje“, Kritik, no. 192, pp. 124-133

Miller, D 1995, On Nationality, Oxford, Oxford University Press.

Miller, D 2007, National Responsibility and Global Justice, Oxford, Oxford University Press.

Modood, T, A. Triandafyllidou \& R. Zapata-Barrero (eds.) 2006, Multiculturalism, Muslims and Citizenship, London, Routledge.

Nussbaum, M.C. 2006, Frontiers of Justice - Disability, Nationality and Species Membership, Cambridge, MA, The Belknap Press of Harvard University Press.

Parekh, B 2006, Rethinking Multiculturalism - Cultural Diversity and Political Theory, Houndmills, Palgrave Macmillan.

Pettit, P 2007, „Responsibility Incorporated“. Ethics, vol. 117, no. 2, pp. 171-201.

Pierik, R 2008, „Collective responsibility and national responsibility“, Critical Review of International Social and Political Philosophy, vol. 11, no. 4, pp. 465-483.

Phillips, A 2007, Multuculturalism without Culture, Princeton NJ., Princeton University Press.

Pogge, T 2006, World Poverty and Human Rights, Oxford, Polity Press.

Rawls, J 1971, A Theory of Justice, Oxford, Oxford University Press.

Singer, P 2009, The Life You Can Save: Acting Now to End World Poveerety, New York, Picador.

Støvring, K 2010, Sammenhangskraft, København, Gyldendal.

Sørlander, K 2008, Forsvar for rationaliteten, København, Informations Forlag.

Taylor, C 1992, „Multiculturalism and the Politics of Difference“, pp. 25-74 in A. Gutmann (ed.), Multiculturalism, Princeton, NJ, Princeton University Press.

Young, I. M. 1990, Justice and the Politics of Difference, Princton, NJ, Princeton University Press. 